\title{
Get Public or Perish
}

Katharine Smithrim, Rena Upitis, Margaret Meban, and Ann Pattesonã 2000

There are a significant number of learned men and women who hold that any successful effort to make ideas lively, intelligible, and interesting is a manifestation of deficient scholarship. This is the fortress behind which the minimally coherent regularly find refuge.

"P ublish or perish" has long been a ground rule in the academy. Universities continue to use articles in refereed journals and scholarly books as the most important criteria for indicating research productivity in promotion, tenure, and merit reviews. Other published material, at least in many of the social sciences, is valued in more or less this descending order: invited chapters in scholarly books, editing of a scholarly book, papers published in refereed conference proceedings (although it's not always clear whether proceedings are refereed). At the bottom of the list are text books, other non-scholarly books and articles in non-refereed publications.

The publications at the top of the above list drive much of the writing, research, and reading that occurs within the academic world. However, there tends to be little readership of these publications outside the world of academia and research. Few such reports of research reach the public. It can hardly be viewed as surprising, then, that government funding for research is coming under increasing scrutiny (Frost, 1995). One of the characteristics of contemporary society is that citizens want a say in all areas of government jurisdiction. People are no longer willing to trust the wisdom, knowledge, and judgment of elected officials. There is also an increasing disregard for the so-called expert in the face of seemingly limitless and easily accessible information. In order to ensure government funding for research in the future, we, as researchers, need to help increase the general public's awareness and understanding of the importance of research. (If you asked your neighbour whether government should continue to fund research in education, what do you think the answer would be?)

In November of 1998, a national meeting took place in Ottawa involving 65 researchers and numerous elected government officials, along with staff from the Social Sciences and Humanities Research Council of Canada (SSHRC), one of several federal granting agencies in Canada that funds the kind of research that is reported at conferences and described in journals like this one. At the meeting, the message was clear: researchers in the Social Sciences and Humanities need to disseminate their research to the public. In his address, Social Sciences and Humanities Research Council of Canada President Marc Renaud coined the phrase "get public or perish", urging researchers to report their work in jargon-free ways to the general public in order to gain public awareness and support for research.

What are some strategies that will bring research into the public domain—strategies that would involve sharing research results enthusiastically, convincingly, and with integrity? We offer our own current research project as an example of how research can be shared with the general public.

\section{Teachers as Artists}


The Teachers as Artists research and teacher development project is in the final year of a four-year project funded to a large degree by the Social Sciences and Humanities Research Council of Canada. Teachers as Artists is about finding sustainable and effective ways to bring the arts to schools that have limited resources for arts programs. The idea is to help teachers become beginning artists, so that they learn to value the arts more deeply and, in turn, seek ways to provide their students with experiences that enhance the presence of the arts in their lives. The entire teaching and administrative staff in a small urban school takes part in workshops, interacts with artists-in-residence, and pursues individual projects in the arts. Every year, a number of workshops are offered by local artists, primarily in music (e.g., guitar, piano) and the visual arts (e.g., print-making, photography, painting, carving). Teachers are also encouraged to pursue one particular art form in depth. The program is designed to take advantage of community strengths in the arts, bringing together teachers and artists with the aim of increasing artistic sensibilities of teachers and ultimately strengthening arts education in elementary classrooms. Results to date attest to the personal and professional transformation of individual teachers. There is also evidence of the emergence of arts advocacy within the community.

Over the past three years, the Teachers as Artists project has been reported at nine national and international academic conferences: The National Arts Education Symposium, Sydney, Nova Scotia, in July 1997; the American Educational Research Association, San Diego, in April 1998; the Canadian Society for Studies in Education, Ottawa, in May 1998; the International Society for Music Education, Pretoria, South Africa, in July, 1998; the National Arts Symposium, Victoria, in July 1998, the Research in Music Education Conference in Exeter, UK, in April, 1999; the Canadian Society for Studies in Education, Sherbrooke, 1999; the Canadian Society for Studies in Education, Edmonton, 2000; and the International Society for Music Education, Edmonton, 2000. Papers for peer-reviewed journals and conference proceedings (e.g., Upitis \& Smithrim, 1998; Upitis, Smithrim \& Soren, 1999) have been prepared-it is vitally important to understand that "getting public" does not mean that more traditional forms of research dissemination are displaced. It means that, in addition to the traditional models, we need to undertake other, more public forms of dissemination.

Our commitment to disseminating the research findings has also included seeking broader audiences than those who might attend conferences or read journal articles. We have been able to accomplish this through a number of vehicles, each embodying a different form of communication strategy and potential audience. Descriptions of the various kinds of non-traditional communication strategies used over the past few years for the Teachers as Artists research follow.

\section{Non-traditional Dissemination of Research}

\section{Broadcast Media}

In the fall of 1997, Joe Coté of Ontario Morning, our local early morning Canadian Broadcasting Corporation (CBC) program host, interviewed Harry Murphy, the principal at one of the research schools, Aggie MacDonald, Educational Assistant, and Katharine Smithrim. The interview was broadcast in January, 1998. One of the routes to securing this interview began with a press release about another small research project. Katharine Smithrim and Jan Le Clair had surveyed faculty, staff and students at the Faculty of Education at Queen's University asking what ten songs every Canadian should know. The results were tallied and e-mailed off as a press release to Ontario Morning. The producer called within half an hour to see if an interview could be arranged for later that morning. Jan Le Clair did the interview, and it was broadcast the following morning. While speaking to the producer, Katharine suggested that he might be interested in another research project which involved supporting classroom teachers in becoming artists. He indicated that 
it would be good to talk about the project at some time.

When Coté was planning a subsequent visit to Kingston, Queen's Communications Department called the Faculty to ask what other "education stories" might interest the Ontario Morning listening public. Linda Ross, the Faculty's Communications and Development Liaison Officer, suggested the Teachers as Artists project, along with several others. The Ontario Morning team chose three projects from across the university for interviews, and the Teachers as Artists project was one of them.

\section{University publications}

The Queen's Gazette, the faculty newspaper at Queen's, published a feature photograph of an exuberant teacher participant playing the guitar, along with a half page article. Melanie Dugan (1997), a freelance writer, had heard about the research project and suggested it to the Gazette editor, offering to write the piece. In addition, promotional material for the University's Capital Campaign also featured the Teachers as Artists research.

\section{Local Newspapers}

Six months later, Dugan called to see if she could write a feature article about our research for Kingston This Week, a local newspaper with a distribution of 48,000 (1998). She visited the school while Margaret Meban, a graduate student and research assistant, was serving as artist-in-residence. The result was a full page feature with two large photographs of the children with their artwork.

\section{Exhibits}

In exhibition of children's art from the research school was mounted in a major local shopping centre during the second year of the project when Margaret Meban served as artist-in-residence at the research school. To celebrate the artwork the students had created during the artist-in-residence program, Margaret organised a public art show where students, teachers, parents, and other members of the community could come and see the paintings created by the children of St. Patrick School.

Finding a location to show children's artwork in Kingston took a bit of perseverance. Many of the vacant downtown locations had legalities involved which prevented a public display, and other possible locations such as the public library and local restaurants were booked up for months. The art show took place at the Kingston Center Shopping Centre which offered a bright atrium, perfect for a display of artwork. The art show exposed the community to the arts development research project at St. Patrick School as the artist, Margaret, was there to talk with the public about the research and the students' artwork. Also, recent newspaper publications and other documentary writings were posted with the art show. Not only did this means of public exposure introduce the Kingston community to our research, but it allowed for an authentic assessment of the students' work. Like "real" artists, students put their work on public display where they received feedback and discussed their work with community members.

\section{School Newsletters}

Short articles about the research have appeared in the school newsletter at our research school. Harry Murphy, the principal at St. Patrick School, wrote short information pieces about the research in nearly every issue. The newsletter goes home with each student in the school several times a year. 
As a result of the visibility of the project, we were invited to provide the text for an entire issue of a research newsletter designed for teachers and distributed to all of our associate schools. Pages From... is an example of an alternate form of dissemination of research. It was developed out of a concern that educational research is largely inaccessible to practicing teachers who are already overburdened. Many have neither the time nor energy to pore over research journals or examine important, but mighty, tomes such as the Handbook of Research on Teacher Education (Sikula, 1996) or the Handbook of Educational Psychology (Berliner \& Calfee, 1996) which are generally accessible only in libraries at Faculties of Education. Pages From... is an educational research digest, with each issue devoted to a topic that is interesting, provocative, and useful to teachers in the field. Contributors are educational researchers at the Faculty of Education, Queen's University, Kingston, Ontario, who are invited to write about their respective research endeavours. Topics have included the following: Teachers' Knowledge, Professionalism, The Arts in Education, and Computer Technology in the Classroom. Funding has been principally provided by the Office of the Dean with additional support from the Office of the Registrar and the Practicum Office at the Faculty of Education.

\section{Federal MP's "Householder"}

One of the strategies suggested at the SSHRC meeting referred to at the opening of the paper was that researchers should talk with their federal Members of Parliament (MP) and explain their research to such elected officials. In these conversations, researchers were encouraged to consider why the MP might be interested in the work and how the research could be related to the MP's current concerns. Rena Upitis and Katharine Smithrim made an appointment to tell our MP, Peter Milliken, about our research and to make sure he knew that our research money provided employment for graduate students. It helped that Mr. Milliken is "arts friendly"- he is a fine bass singer who has sung in choirs for many years. Because of his experiences as a graduate student, he was aware of how research funding worked. Most MP's are quite relieved to have someone come to talk with them without demands or requests for help. Rena and Katharine were surprised when Peter asked if there was anything he could do to help them. It was his idea to feature our research in the newsletter The Milliken Report which he sends quarterly to the 40,000 households in his riding. The research team provided photographs and the text, and his staff did all the layout, production, and distribution. Mr. Milliken also offered to show our video in some of his time slots on the local cable TV network.

\section{Website}

One of the graduate student research assistants, Nathalie Sinclair, created our web page http://educ.queensu.ca/ arts. The web page includes information about the project and the research team, photographs, and all the published research papers. A website is also referred to in other publications (e.g., the "glossy", described below) and is linked to the researchers' home pages. This allows us not only to profile the research, the artists, teachers, and other team members, but it also permits us to share current information and research findings. The website is becoming more and more important as people come to use the Internet on a more regular basis.

\section{Video}

We used some of our research funding to create a six-minute video designed for workshop, conference, and other presentations. It has also been used to describe our project to other schools interested in taking part in the expansion of Teachers as Artists program. We used photographs and video footage of workshops and interviews, and overdubbed a narration. Queen's TV produced the video for $\$ 650.00$. 
In addition to the video, the other financial outlay for dissemination was the production of a "glossy" brochure about the research for just over a dollar per copy. These glossies are handed out at conferences, mailed out when inquiries come in, and accompany press releases and other communications. Faculty post them on office bulletin boards, and they are available in the waiting area outside the dean's office for visitors to take with them.

\section{Concluding Remarks}

Doing this kind of advocacy for research is-like any other enterprise-time- consuming and resource intensive. Professional public relations people say it takes a day to put together a good press release and ten hours of production time per minute of video. One of the things that our research team does is examine strategies for "getting public" that are within our grasp as researchers in the academy, with limited funds and limited time. We found, for instance, once we began this public dissemination process, that we could use the same text for many purposes. Similar text appeared in Pages From (the research newsletter for teachers in associate schools), the Milliken Report from our Member of Parliament, the glossy, and the video narration. Because our research group is committed to public dissemination of research, we include significant and appropriate time and money in our research budget for producing materials for public dissemination. In a recent grant proposal to SSHRC, we also included details about these supplementary forms of dissemination in our application (the grant proposal was successful).

In the process of doing this work, we have asked what have sometimes been difficult and uncomfortable questions, namely: What captures the imagination of the public? How can this kind of non-traditional promotion and dissemination of research be honoured in the academic system of tenure and promotion? How can public relations be a form of education? and — coming back full circle to where we began-How can we communicate results with integrity without relying on academic jargon?

\section{Communicating without jargon}

All the writing for these newsletters and articles was done as a team effort with individual members of the research team writing the various segments. Everyone on the team read and edited all the parts, initially over e-mail, then on paper. The goals of the writing were interest, clarity, and fluidity. The first rule in communications is that we need to communicate in a way that the receiver understands. Academic writing is often dense, erudite and intimidating. It can be much more difficult to explain our research in a lively and interesting fashion than to hide behind a jargon-laden discourse so dense that only those who understand the jargon can have access to the ideas thus described. Gerry Spence, writer and attorney, claims to have never lost a criminal trial. His notable cases, including the Karen Silkwood and Randy Weaver trials, number in the hundreds. Spence (1995) speaks about effective spoken and written language in this way:

Words that do not create images should be discarded. Words that have no intrinsic emotional or visual content ought to be avoided. Words that are directed to the sterile intellectual head-place should be abandoned. Use simple words, words that create pictures and action and that generate feeling (p. 104).

In the context of her responsibilities for fund-raising and communications, Linda Ross (Communications and Development) had a conversation with the demographer and economist David Foot. Foot regularly keeps his audience on the edges of their seats during his lectures for which he charges in excess of $\$ 5,000$ a session. Linda asked him if he was just naturally a good communicator. He laughed and told her that it took a focussed, disciplined effort to learn to communicate effectively, adding that the most important (and most difficult) challenge in learning to communicate was to take every piece of jargon out of one's work. 
How then, do we write for the public? Rena Upitis (1999) suggests we write text for taxi drivers, claiming that many taxi drivers are keen observers and critics of human behaviour. She also points out that many taxi drivers have firm ideas about how society should change and, further, that they pay taxes and have something to say about education and about educational research. In a recent keynote address at a Conference of Research in Music Education in Exeter, England, Upitis claimed

If you can't tell a taxi driver or a check-out clerk at the grocery store about your research, then you haven't developed a way to tell your story so that your work will make a difference (p. 224).

Upitis then issued a challenge to her Exeter audience: "Can you describe your research in one or two sentences—what you do and why it matters?" (Upitis, 1999, p. 224).

If we are going to gain the support of the general public for government funded research, we must talk about our work in clear and interesting ways in the public domain.

Capturing the imagination of the public

Demographers tell us that the population is more educated generally and that the baby boomers who are filling up the board rooms care about education, health care, jobs for their children, and their own continuing needs. We need to appeal to these interests. Because there is so much information out there, we have to present our work in ways that make it rise to the top. There are, in our experience, two areas that capture public interest in arts education. The first is research on brain development; the second is the relationship between arts and academic achievement in other subjects. These are a far cry from the reasons that art education is important for those who value the qualities intrinsic to the arts. But we are beginning to understand that unless we can report our research in ways that capture the public's imagination-by relating arts education to issues of academic achievement, for example-we will never get the chance to talk about how the arts enrich our lives and understanding of human experience.

An example of what captures the interest of the general public is the popularization of the so-called Mozart effect research (Rauscher, Shaw \& Ky, 1995), where, in limited circumstances, it has been demonstrated that listening to Mozart increases performance levels on other cognitive tasks. It seems that parents want to do everything they can to make their babies and children "smarter". There is a dubious connection between this 'make your baby smarter' claim and the original research, but it has been convincing enough for the public that several American states now send home a Mozart tape with every baby born in hospital.

In our experience, statements about increased academic achievement (e.g., higher SAT scores lower drop out rates, Music in World Cultures (1996), especially if student family income and education levels are taken into account (Catterall, 1998)), provide the type of information that makes the public listen more closely to research about arts education (Upitis, 1999). Further, any research on brain development (e.g., Begley, 1996) is also likely to fuel lively public discourse. But it is nevertheless critical to both examine the claims of research closely, and to ensure that these results alone are not used to justify the importance of arts education. The "Mozart effect" example serves to illustrate a potential problem with "getting public" and that is that the public statements are often taken at face value and generalized without supporting evidence. There will always be a role for researchers to examine such public statements with scrutiny, as well as to make public statements with great care.

Non traditional forms of dissemination in the academic system of tenure and promotion 
Not only do we need to communicate to the public, we need to convince the administrators and academic heads of our universities of the importance of broad dissemination of research. Indeed, in a recent memo (File \#2026-1; May 21, 1999) to the Research Administrators in all Canadian universities, the Social Sciences and Humanities Research Council (SSHRC) announced that the 10\% ceiling for costs associated with research dissemination was to be lifted. These kinds of directives are helpful in exerting pressure on those who create and monitor criteria for assessing appointments, promotions, and tenure to include expectations that candidates provide evidence for some forms of public dissemination of their work.

\section{Public relations as a form of education}

Most of us who are involved in educational research are also educators. We take seriously our teaching responsibilities with our students, and those in Faculties of Education are also expected to model effective teaching. We are now being called upon to turn our pedagogical skills toward a new audience-the general public. We already have many of the necessary skills; we have simply been unaware of the growing need for the task. This work will not show up as a figure in our teaching or research workload, and yet it may be what saves our ability to carry out SSHRC funded research.

Following the meetings with the MPs in November of 1998, the SSHRC president also implored researchers to write letters to support a recent increase in SSHRC funding announced by the federal Minister of Finance, Paul Martin. Rena Upitis did so-in fact, she wrote a half dozen such letters, with copies to the SSHRC president. Upon receiving the copies of those letters, the SSHRC Government Relations Officer sent Upitis a warm note of thanks, stating that she was one of few who had followed through with letters, ending with this rather telling note of caution: "We are wondering if we haven't seriously underestimated the time and resources that [researchers have] to devote to this kind of promotion activity" (personal communication, April 9, 1999; J. Charron, Government Relations Officer, SSHRC).

We have been issued a strong warning that in order to maintain public support for research, we, the researchers, are going to have to demonstrate the importance of our work to the general public. Some may squirm and say that it is a waste of time, that professors are not in the publicity business, that the academic mission is to embody excellence in teaching and research, not advertise. Those things may be true, but so is the risk of losing government research funding if we do not take on the responsibility of communicating the importance of our research to the general public enthusiastically, convincingly, and with integrity.

\section{Acknowledgements}

An earlier version of this paper was presented at the Canadian Society of Studies in Education (CSSE) Annual conference, Sherbrooke, Quebec, June 1999 by the authors and Nathalie Sinclair and Linda Ross of the Faculty of Education. Preparation and presentation of the paper was supported in part by SSHRC Grant \# 410-97-0805, Teacher Development and Elementary Arts Education (R. Upitis, Principal Investigator).

\section{References}

Begley, S. (1996). Your child's brain. Newsweek, February 19, 1996.

Berliner, D.C., \& Calfee, R.C. (Eds.). (1996). Handbook of educational psychology. New York: Macmillan

Reference Library.

Catterall, J. (1998). Does experience in the arts boost academic achievement? Art Education, 51(3), 6-11. 
Dugan, M. (1997, November 17). When teachers become artists. Queen's Gazette, p. 2.

Dugan, M. (1998, May 2). Reading, writing, arithmetic_-and art. Kingston this week, p. 1 C.

Frost, B. (1995). Strategies for facilitating the development of scientists and scholars: A personal view.

Colloque sur le pinanement de la recherhe: Évolution et impact sur la formation de la releve et le financement étudiant. Montréal: Université de Montréal.

Music In World Cultures. (1996). The Georgia project: A status report on arts education in the State of

Georgia. St. Bonafice, MN: Author.

Rauscher, F.H., Shaw, G.L.,\& Ky, K.N. (1995). Listening to Mozart enhances spatial-temporal reasoning: toward a neurophysiological basis. Neuroscience Letters, 185, 44-47.

Sikula, J. (Ed.). (1996). Handbook of research on teacher education (2nd ed.). New York: Macmillan Reference Library.

Smithrim, K., Upitis, R. \& Le Clair, J. (1999). When classroom teachers become musicians and artists.

In B. Hanley, (Ed.) Leadership, advocacy, communication: A vision for arts education in Canada.

Toronto: The Canadian Music Educators Association, pp. 93-106.

Spence, G. (1995). How to argue and win every time. New York: St. Martin's Press.

Upitis, R. (1999). Artistic forms of research. Music Education Research, 1(2), 221-227.

Upitis, R. \& Smithrim, K. (1998). Teacher development and elementary arts education. In B. Roberts,

(Ed.). Connect, combine, communicate: Revitalizing the arts in Canadian schools. Sydney, NS:

University College of Cape Breton Press, pp. 207-222.

Upitis, R., Smithrim, K. \& Soren, B. (1999). When teachers become musicians and artists: Teacher transformation and professional development. Music Education Research, 1(1), 23-35. 